\title{
On the Brazilian ground-rent appropriated by landowners
}

\author{
Renda fundiária brasileira apropriada \\ por proprietários de terras
}

NICOLAS GRINBERG*

RESUMO: Este artigo apresenta uma medida da parcela de renda fundiária brasileira apropriada por proprietários de terras agrárias durante 1955-2005 e avalia sua importância em relação a outras formas de valor excedente apropriado na economia brasileira. $\mathrm{O}$ trabalho também apresenta estimativas originais de várias de séries temporais que são cruciais para o estudo do crescimento brasileiro de longo prazo e desenvolvimento. Finalmente, o papel combina as medidas obtidas com as de Grinberg $(2008,2013 b)$ para apresentar uma aproximação para a evolução do total da renda fundiária brasileira durante 1955-2005. O apêndice apresenta as fontes e a metodologia utilizadas para as estimativas. PALAVRAS-CHAVE: Brasil; desenvolvimento econômico; renda fundiária.

ABSTRACT: This paper presents a measurement of the portion of the Brazilian groundrent appropriated by agrarian landowners during 1955-2005 and assesses its importance relative to other forms of surplus value appropriated in the Brazilian economy. In pursuing this task, the paper also puts forward original estimations of several time-series that are crucial for the study of Brazilian long-term growth and development. Finally, the paper combines the measurements obtained here with those advanced in Grinberg $(2008,2013 b)$ to present an approximation to the evolution of the total Brazilian ground-rent during 1955-2005. The appendix presents the sources and methodology used for the estimations. KEYWORDS: Brazil; economic development; ground-rent.

JEL Classification: N5; Q1; O1.

\section{INTRODUCTION}

The Brazilian economy has recently undergone a period of strong growth that put it back at the centre of the international stage. It is widely agreed that this

\footnotetext{
* Consejo Nacional de Investigaciones Científicas y Técnicas (CONICET) and Instituto de Altos Estudios Sociales (IDAES) de la Universidad Nacional de San Martin (UNSAM). E-mail: n.grinberg@gmail.com. Submitted: 21/January/2014; Approved: 9/October/2014.
} 
growth has been underpinned by the strong performance of primary-sector production. Indeed, Brazil has become a leading producer and exporter of a wide (and widening) range of agrarian and mining commodities. This, however, is hardly a new phenomenon. Despite the many differences that exist between this period and those that preceded it, a key characteristic of the Brazilian economy throughout its entire history has been its participation in the global economy as a producer of primary commodities. For neoclassical economists, this has no relevant implications. Yet, raw materials production exhibits a specific characteristic that distinguishes it from industrial production. The prices of primary commodities are not regulated by normal but marginal conditions of production and thus include a rent for the use of the irreproducible means of production, land (Marx, 1981). In primary-commodity producing economies, like the Brazilian, a relatively large portion of social wealth then takes the form of ground-rent.

The goal of the present paper is to complete the measurements of the historical evolution of the Brazilian ground-rent advanced in Grinberg (2008, 2013), presenting an estimation of the portion appropriated by landowners. In pursuing this goal, this paper will put forward the methodology and original estimation of a group of macroeconomic time-series that are also required for the analysis of the long-term performance of the Brazilian economy. For that purpose, the paper is organised as follows. The next section discuses the determination of the capitalist ground-rent and analyses its role in structuring the Brazilian process of capital accumulation. The third section presents an estimation of the ground-rent appropriated by landowners in Brazil. Fourth section puts together the results of the previous section with the measurements presented in Grinberg $(2008,2013 \mathrm{~b})$ to produce an estimation of the total ground-rent available for appropriation in Brazil. Fifth section assesses the relative importance of ground-rent in the the production and appropriation of social wealth in the Brazilian economy. The last section closes the paper with some conclusions.

\section{GROUND-RENT AND CAPITAL ACCUMULATION IN BRAZIL}

As noted above, the commercial prices of primary commodities are, unlike those of industrial commodities, regulated by those marginal conditions of production that need to be used to satisfy solvent demand. Effectively, in order to supply the demanded commodities, primary-sector capital must valorise, as any other productive capital, at the general rate of profit. Hence, the prices of primary commodities must be sufficiently high to allow capital using lowest-quality lands to compensate for the low productivity of the labour they set in motion. Competition to use infra-marginal lands, where relatively favourable and irreproducible natural conditions enhance the productivity of labour and thus reduce production costs, transforms potential surplus-profits into rent paid for the use of land, ground-rent (Ricardo, 2001, pp. 39-53; Marx, 
1981, pp. 779-811; Iñigo Carrera, 2007, pp. 11-3). ${ }^{1}$ Likewise, if successive applications of capital of a given size, each yielding different output, need to be undertaken on plots of land of different quality already under production to satisfy solvent demand, infra-marginal portions of capital also yield surplus profit, even those applied to worst-quality lands (Ricardo 2001, pp. 43-4; Marx 1981, pp. 812-23). ${ }^{2}$ Competition by individual capitals also transforms these surplus profits into ground-rent. ${ }^{3}$ Both the extensive and intensive types of differential rent spring from the monopoly by landowners over portions of the planet that yield a different output, and thus profits, for capitals of similar magnitude. Their existence is a concrete form of realisation of the equalisation of the rate of profit among individual capitals.

This monopoly over differential conditions of production stands on an absolute monopoly over this irreproducible means of production which becomes apparent in the case of worst-quality lands. Indeed, since, contrary to Ricardo (2001), their owners would not allow their productive use by capital without also receiving a payment in exchange, commercial prices of primary commodities must rise further above the price of production (i.e., the price that covers for normal production costs and average profits) corresponding to the output of worst-quality land (or, more precisely, lowest-yielding portions capital) in order to include a rent springing from the absolute monopoly by landowners of a means of production that cannot be produced by human labour. Unlike the differential ground-rent, the magnitude of the rent of absolute monopoly (both the absolute rent and rent of simple monopoly) varies not according to soil quality (or location) but to landowners' bargaining power vis-à-vis productive capital (Marx, 1981, pp. 882-907; Iñigo Carrera, 2007, pp. 13-4).

In sum, their monopoly over natural conditions of production that increase labour productivity, or permit it altogether, allows landowners to appropriate a portion of social wealth without actively contributing to its creation in any sense whatsoever. In contrast to what occurs in the industrial sector, these conditions cannot be reproduced by capital and generalised; surplus profits appropriated by landowners thus become rent (Marx, 1981, pp. 783-4, 891-8).

In Brazil, the rent of agrarian and mining grounds have been substantial during most of the country's history; not only due to the large availability of productive

\footnotetext{
${ }^{1}$ The marginal land is, by definition, the one where, ceteris paribus, capital sets in action the lowest level of labour productivity. This does not mean, however, that the last land brought into production to satisfy social demand is, by definition, the marginal one. Yet, it means that, unless all lands are of the same quality, at any moment there would be a plot of land which is the marginal one.

${ }^{2}$ In primary production, crucially in the agrarian sector, the different successive (discrete) applications of capital do not change, as in industrial activities, the quality of the output. They simply change its quantity. Each portion of capital is thus associated with a different level of labour productivity. See Iñigo Carrera (2007, pp. 102-3).

${ }^{3}$ Equally, if rural (or mining) wages are particularly lower than urban wages, for reasons other than differences in the cost of reproducing both types of labour-power in the conditions required by capital, the rate of profit would, ceteris paribus, be higher in the rural than in the urban sector. Competition among capitals to appropriate these extraordinary profits would transform them into ground-rent. See Marx (1981, pp. 765, 890).
} 
lands, and thus the extended production of rent-bearing (i.e., primary) commodities, but also due to the relatively favourable natural conditions for primary-commodity production prevailing in vast areas of its territory, and thus the high average rent materialised in them. These conditions have determined Brazil's role in the production of relative surplus-value on a global scale and thus its participation in the international division of labour as a producer of primary commodities. To the extent that rent-bearing commodities have been consumed outside the Brazilian economy, ground-rent has constituted an inflow of social wealth to there.

This characteristic of the Brazilian economy has not been simply a formal difference with the industrially advanced ones. On the contrary, it has determined its specific structure and long-term development. The process of capital accumulation in Brazil has, since its origins, revolved around the recovery of ground-rent by industrial capital (Grinberg, 2013a), as has been the case in most countries incorporated into the international division of labour as primary-commodity producers (Iñigo Carrera, 2008). Effectively, Brazil's original subsumption into the global circuits of accumulation as a producer of primary commodities was ridden with a genetic contradiction that determined its long-term pattern of capitalist development. If, on the one hand, the total capital of world society enhanced its valorisation capacity by reducing the value of means of consumption and hence labour-power, on the other, this was partly offset by the drain of surplus-value flowing into the pockets of landowners in the form of ground-rent. Industrial (i.e., productive) capital became, then, driven to overcome this barrier to its accumulation capacity by establishing an antagonistic association with local landowners in order to recover part of that surplus-value. Hence, from being simply a source of relatively cheap primary commodities, Brazil, as most other raw-material producing colonies/nations, became determined, also, as a source of ground-rent for global industrial capital (Grinberg and Starosta, 2014).

From the Colonial period to approximately the 1930s, the alliance between capital and landowners over the appropriation of the ground-rent revolved around the production, transport and international trade of various primary commodities. During that period, capitals invested in these and related sectors, as well as foreign creditors, became landowners' main partners in the appropriation of the Brazilian ground-rent. However, incipiently since the 1930s, and crucially the end of WWII, this position was taken over by industrial capital invested in manufacturing in whose cycle of valorisation most of the ground-rent originated.

The accumulation of capital through the appropriation/recovery of a portion of the Brazilian ground-rent has taken a variety of forms; all of them have involved the mediation of the national state though its policies and activities. The process of import-substituting industrialisation (ISI) - consolidating at the end of WWII, reaching its peak during the 'commodities boom' of the 1970s and reproducing in a limited form thereafter - has been the general politico-economic form through which this specific modality of capital accumulation has come about. In general terms, two types of policy-created mechanisms, indissolubly united, have given form to the process of ISI as form accumulation through ground-rent recovery. Some 
state policies have intervened in the turnover cycle of primary-sector capital, separating a portion of ground-rent and thus interrupting its flow towards landowners' pockets. These have included exchange-rate overvaluation, taxes on primary-commodity exports and state control over their domestic and international trade. ${ }^{4}$ All of these policies have transferred a portion of ground-rent to privately-owned industrial capitals, by setting domestic prices of raw materials and means of consumption (and thus labour-power) below their international levels ${ }^{5}$ and, in the case of the overvaluation of the currency, by reducing the local price of foreign exchange for specific imports and profits repatriation. ${ }^{6}$ These policies have also transferred a portion of ground-rent to the state not only directly (through the monopoly/control of foreign-exchange markets and primary-commodity trade or the taxation of raw-material exports), but also indirectly (through the payment of relatively high import taxes and other import-related duties with an overvalued currency). Simultaneously, other policies have allowed the appropriation of the separated portion of ground-rent by industrial capital either through 'market mechanisms' or direct state actions. These have included: the calibrated protection (higher for final goods than for inputs and machinery) of the domestic markets where internationally-small industrial capitals realise the appropriation/recovery of ground-rent; the provision of services, industrial inputs and credit at subsidised rates by state-owned companies and banks; the regulated expansion of domestic markets through their activities (i.e., the purchase of locally produced goods and services at inflated prices and an oversized workforce); and, direct subsidies or tax credits. In other words, policies associated with ISI - both in their extended, 'classic', and in their limited, 'neoliberal', forms - and the political processes through which these have come about, have been the specific politico-economic forms of realisation of processes of accumulation based on the appropriation/recovery of ground-rent by global industrial capital (see Grinberg, 2013a; Grinberg and Starosta, 2014).

This specific modality of accumulation has allowed industrial capital to recover part of the Brazilian ground-rent. However, it has rested on inherently contradictory foundations. In order to accomplish the appropriation of ground-rent, industrial (manufacturing) capital has had to open and close its valorisation cycle in the Brazilian domestic market. Otherwise, competition to sell (buy) there above (below) world-market prices would have left the rent in the hands of landowners. As a consequence, the domestic market has had to remain protected to a degree conditioned by the amount of ground-rent available to sustain local industrial produc-

\footnotetext{
${ }^{4}$ See Bresser-Pereira $(2008,2013)$ for an alternative account that also relates causally exchange-rate overvaluation to the existence of 'natural resource' rents. This author finds in the Ricardian rents the cause of the market failure known as Dutch disease - i.e., the tendency of the Brazilian currency to become overvalued.

${ }^{5}$ National accounts thus underestimate the real weight of primary production in the Brazilian economy.

${ }^{6}$ Profit-rate-equalising competitive pressures have passed the 'discount' from exporters to agrarian capitalists and from these onto landowners; and from internationally- to domestically-traded primarycommodities.
} 
tion. Indeed, unable to produce for world markets, and thus compete with those industrial capitals that had engendered the Brazilian process of accumulation, the scale of production of industrial capital operating there became since its origins limited to the size of the domestic market. With a scale of accumulation below world-market norms, the use of frontier technology has remained restricted, let alone its development. In addition, policies maximising the appropriation of ground-rent by industrial capital, crucially exchange-rate overvaluation and market protection, have reinforced this restriction further, as noted elsewhere (see, e.g., Bresser Pereira, 2008, 2013) among others. ${ }^{7}$ Hence, though, on one hand, foreign-owned industrial capital has managed in this way to valorise normally while recycling obsolete equipment and avoiding competition in world markets with parent houses, on the other, its accumulation capacity has depended, as that of locally-owned capital, on the evolution of the magnitude of the ground-rent available for appropriation. Not only because to reproduce on an expanded scale industrial capital has required, ceteris paribus, a growing amount of ground-rent, but also to compensate for the ever-growing difference between local and world-market production costs, in turn resulting from the difference between local and world-market scales of production and their impact upon technological profiles and, thus, levels of labour productivity. ${ }^{8}$ Moreover, by lowering primary-commodity domestic prices, the forms of appropriation of ground-rent by social subjects other than landowners have restricted the intensive and extensive application of capital to primary production and, thus, the growth of primary-commodity production and the available ground-rent. In other words, these policies have pushed out of production portions of capital that, without them in place, would have yielded normal profits and some rent (Iñigo Carrera, 2007b, pp. 101-22).

Between the end of the WWII and the mid-to-late-1970s, the amount of ground-rent available for appropriation in Brazil increased strongly and remained, in general, sufficient to sustain the expanded reproduction of capital accumulation, especially during the 'commodity booms' associated with the Korean War (1950-53) and the First Oil Shock (1973-74) which created the bases for the so-called 'state-led' ISI process and marked its peak, respectively. The strong growth of the global economy was then sustaining the demand for raw materials, especially those of agrarian origin. Moreover, since 1968, the expansion of global credit markets, crucially that of Eurodollars, gave place to a large inflow of loanable capital which complemented, as junior partner, the ground-rent in sustaining the process of ca-

\footnotetext{
${ }^{7}$ Exchange-rate overvaluation maximises the appropriation of ground-rent by industrial capital for two reasons. First, because it somehow hides the underlying content of the policy and its extent. Secondly, because it channels ground-rent directly into the profits of industrial capital, without further mediation of the state.

${ }^{8}$ Between the end of WWII and the present, the productivity of Brazilian industrial labour has fluctuated around 20-30 per cent of US levels which, given the much lower initial level of the former, implies an almost constantly widening absolute gap between the two (Grinberg, 2013a, p. 197). See also Salama (1978) on this point.
} 
pital accumulation through ISI. Under these favourable conditions, the Brazilian economy and industrial value-added grew strongly, at 7.5 per cent and 10 per cent annual average, respectively. In the mainstream section of the industrial sector, employment expanded 4.7 per cent per year average while real wages grew at around 3.5 per cent to reach 54 per cent of US purchasing power levels in 1980 (Grinberg, 2011).

Throughout the mid-to-late-1970s, however, the prices of raw materials entered, after the short-lived 1973-75 boom, into a prolonged period of contraction, which affected negatively the evolution of the Brazilian ground-rent (Radetzki, 2006). The slow-growing, or even stagnating, ground-rent became, then, increasingly complemented by rapidly expanding inflows of foreign loanable capital. Yet, though global credit supply has been expanding worldwide ever since (as a form of postponing the general crisis of overproduction), the process has not been constant (Brenner, 2006; Iñigo Carrera, 2008, pp. 181-233). It has taken the form of an alternation of periods in which fictitious capital and, consequently, global credit supply expand rapidly and sustain world consumption, including that of raw materials, and eventually credit flows to 'developing' countries, with periods in which the opposite occurs. Still, even if sporadically enlarged and complemented with large inflows of loanable capital, the Brazilian ground-rent has proved altogether incapable of sustaining the previous scale of accumulation, especially in the industrial sector. The ever-widening productivity gap and the emergence of new sources of cheap labour around the developing world have increased substantially capital's requirement of these resources to valorise normally.

The slow growth of the ground-rent relative to industrial capital's requirements has not only resulted in substantially weaker growth than during the pre-1980 period and in the partial reversion of the previous process of state-promoted industrial 'deepening'. Indeed, measured in domestic currency of constant purchasing power, GDP grew at only 0.6 per cent annual average between the early 1980s and the early 2000s, before the recent 'commodity-price boom' and the concomitant expansion of the Brazilian ground-rent partly reversed the trends, while industrial value-added shrank by 44 per cent. ${ }^{9}$ As a consequence of this development, capital has increasingly relied on even weaker sources of extraordinary social wealth to complement normal surplus-value: the payment of labour-power below its value and, crucially during the 1990s, the resources raised through the sale of state-owned assets at fire prices. Hence, the 'developmentalist' policies of the high-rent, high-growth pre-1980 period gave way to a broadly, and increasingly, neoliberal state. The latter has mediated politically these transformations in the economic content of the Brazilian process of capital accumulation. Though the policy shift slowly began in the early 1980s under the military, neoliberal policies peaked during the democratic governments of the 1990s. By then, the existence of an increasingly

\footnotetext{
${ }^{9}$ See the methodological appendix below on the merits of different consumer price indices alternatively used for this calculation.
} 
large industrial reserve army dispensed capital to rely on politically expensive solutions to push down wages (Grinberg, 2013a).

Grinberg $(2008,2013 \mathrm{~b})$ presented an estimation of the magnitude of Brazilian (agrarian and mining) ground-rent appropriated by capital, crucially in the industrial sector, between 1955 and 2005. Figure 1 reproduces the results of those measurements.

Figure 1: Ground-rent appropriated by others

than landowners - in million $2004 \mathrm{R} \$$

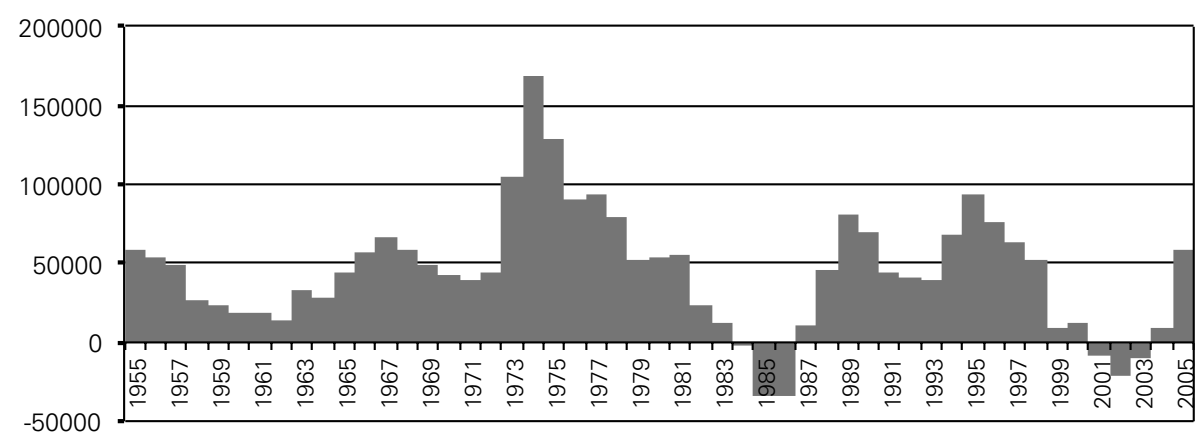

Source: Grinberg (2011).

As can be seen in Figure 1, the amount of ground-rent appropriated by others than landowners has been substantial during most of the 1955-2005 period, crucially during the 'commodities boom' of the 1970s. It can also be seen there that during 1984-86 and 2001-03 a peculiar situation emerged: landowners became able not only to appropriate the entire, albeit significantly reduced, rent but also managed to appropriate a portion of surpluses other than ground-rent - that is, of normal or ordinary surplus-value. This is reflected in the negative sign of the values of the time-series during those years.

The magnitude of the ground-rent appropriated by others than landowners has depended, ceteris paribus, on the total size of the Brazilian ground-rent. In other words, the larger the total available ground-rent, the larger the size of the portion potentially appropriated by social subjects other than landowners. The remainder of the paper complements the measurements advanced in Grinberg $(2008,2013 \mathrm{~b})$, presenting an estimation of the portion of the Brazilian ground-rent effectively appropriated by agrarian landowners, and assessing its relative importance. ${ }^{10}$

\footnotetext{
${ }^{10}$ The computation presented here will not include the portion of the ground-rent appropriated by mining landowners. The estimation of the stock of capital invested in mining production is beyond the scope of this paper. Yet, because the state has been the owner of mining lands, and until the 1990s in charge of production, most of the ground-rent has been transferred to private capital through the commercial activities of mining companies (i.e., through low output prices, high prices paid for procurements and overstuffing) or the general activities of national state.
} 


\section{MEASURING THE GROUND-RENT APPROPRIATED BY LANDOWNERS IN BRAZIL}

The magnitude of the ground-rent effectively appropriated by agrarian landowners is calculated as a residual equal to the sector's value added minus the consumption of fixed capital, the cost of the labour-force used for productive purposes and the profits normally corresponding to agrarian capital. ${ }^{11}$ The latter are calculated using the rate of profit of industrial capital as a proxy and the amount of capital (fixed and circulating) advanced in the agrarian sector. On average, competition should make both profit rates (agrarian and industrial) approximately equal for individual capitals of a given size. A caveat should be made here, however. For reasons associated to the material characteristics of agrarian productions, small capitals tend to be more common in the agrarian than in the industrial sector. The normal rate of profit of agrarian capital thus tends to be, ceteris paribus, lower than that in the industrial sector. Using the average rates of profits in the latter as a proxy for the former thus slightly underestimates the magnitude of the ground-rent effectively appropriated by landowners. The following formula thus measures the annual ground-rent appropriated by landowners (LR). ${ }^{12}$

$$
\begin{gathered}
L R_{i}=V A_{i}-W_{i}-C F K_{i}-\Pi a g r_{i} \\
\prod a g r_{i}=\operatorname{\pi ind}_{i} * \mathrm{Kagr}_{i}
\end{gathered}
$$

Where,

$V A_{i}$ is the value added in the agrarian sector during year $i$;

$W_{i}$ is the cost of the rural labour-force during year $i$;

$\mathrm{CFK}_{i}$ is the consumption of fixed capital during year $i$;

$\prod a g r_{i}$ is the mass of agrarian capital profits during year $i$;

$\pi i n d_{i}$ is the rate of profit of industrial capital during year $i$;

$\mathrm{Kagr}_{i}$ is the amount of capital advanced in the agrarian sector during year $i$.

The remainder of this section will present the results of the measurement of each of these variables and comment upon them. Some of the time-series needed for the measurements in question are readily available. Others need to be estimated. The methodology and sources used to compute all time-series used in the measurements are presented in an appendix at the end of the paper.

\section{Value of agrarian and industrial product and their constituent parts (wages, surplus-value and fixed capital consumption)}

\footnotetext{
${ }^{11}$ The portion of ground-rent appropriated by others than landowners is already deducted from the sector's value added account in the form of policy-induced lower prices of primary sector output or higher prices of its inputs.

${ }^{12}$ See Iñigo Carrera (2007) for the original development for the Argentinian case of the methodology presented in this paper.
} 
In order to measure the rate of profit, the mass of surplus-value appropriated by capital needs to be compared with the capital advanced to obtain it. The annual mass of surpluses appropriated by capital in each branch of production is equal to the value added in that sector minus the consumption of fixed capital and the cost of labour-power (i.e., total wages plus total employer contributions to social security) used in the production process, as shown in the following formula. ${ }^{13}$

$$
\Pi_{y i}=V A_{y i}-C F K_{y i}-W_{y i}
$$

Where,

$\Pi_{y i}$ are total surplus-value appropriated in the sector $y$ the year $i$;

$V A_{y i}$ is the value added in the sector $y$ the year $i$;

$C F K_{y i}$ is the fixed capital consumed in the sector $y$ the year $i$;

$W_{y i}$ is the cost of labour-power in the sector $y$ the year $i$;

Figures 2 and 3 plot the evolution of the different components of the value of agrarian and industrial product, respectively. The portion of ground-rent (GR) appropriated by others than landowners - mostly outside that the primary sector - is added to the value of agrarian product appropriated in the sector. In the absence of state policies transferring ground-rent to social subjects other than landowners, this portion would appear in the national accounts as part of the value of primary-sector product. As mentioned, the evolution of this portion of social wealth was estimated in Grinberg $(2008,2013 b)$. Two caveats, however, should be introduced here. First, as noted above, in the measurements presented here that portion includes mining ground-rent appropriated by others than mining landowners. Second, it also includes ground-rent appropriated by agrarian capital through low-priced equipment and inputs. Though both variables are relatively small, their inclusion somehow overestimates the measure of the value of agrarian product offered in Figure 2.

Several comments can be made on the Figures 2 and 3. First, it can be gathered that both the value of agrarian product appropriated in the sector and of industrial output expanded strongly during most the period up to the mid-1980s and collapsed thereafter. The mass of wealth produced in the agrarian sector, however, peaked during the 'commodities boom' of mid-1970s rather than during the mid-1980s. Secondly, it can also be seen that the mass of surplus-value (net surpluses) appropriated in the agrarian and industrial sectors roughly followed the evolution of the value of output. Yet, in the industrial sector, it expanded more strongly than the value of output during the post late-1990s recovery as the wage mass remained practically stagnant. Though employment expanded, wages fell well below those prevailing in the 1980s.

${ }^{13}$ This is irrespective of how these profits are divided according to capital's ownership. 


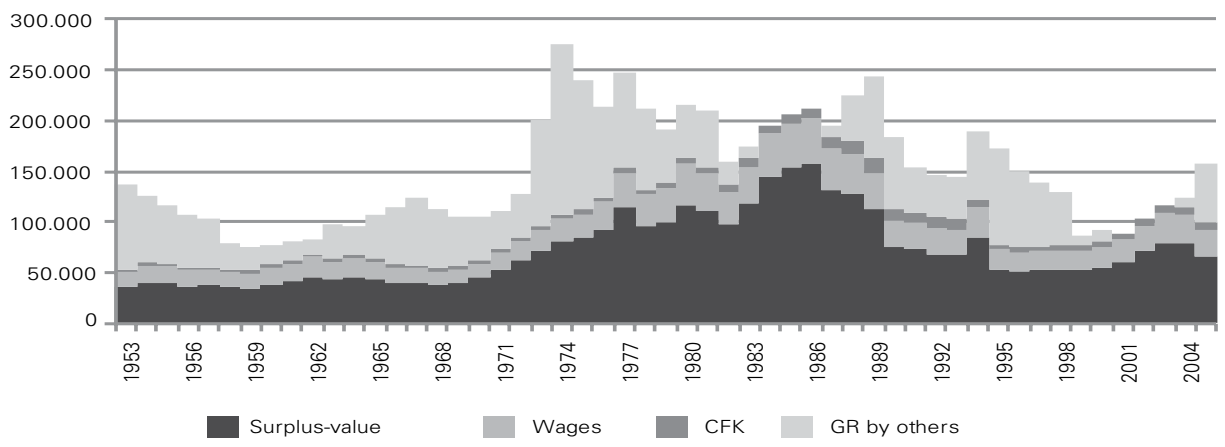

Source: Grinberg (2011).

Figure 3: Value of industrial product - in million $2004 \mathrm{R} \$$

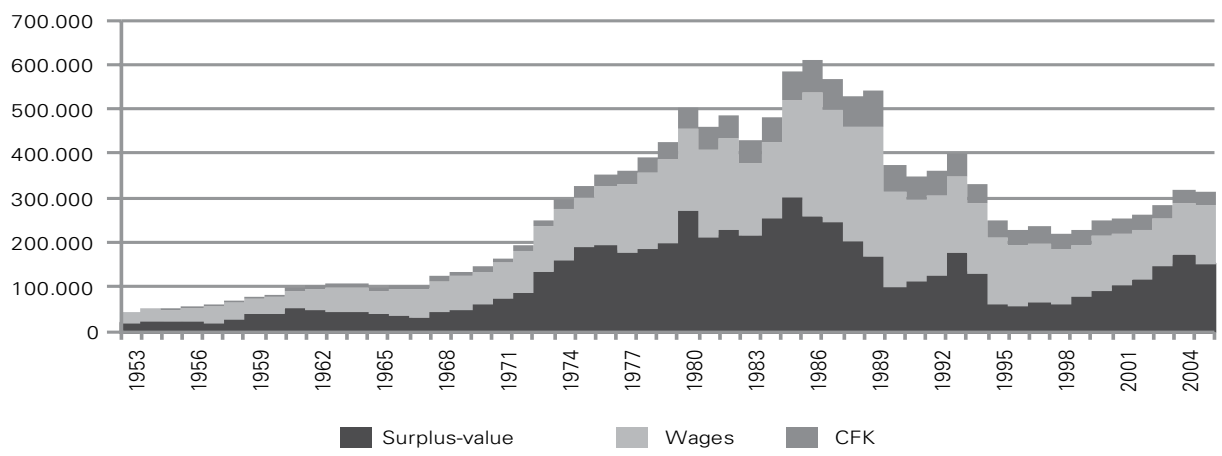

Source: Grinberg (2011).

\section{Capital yearly advanced for valorisation in the industrial and agrarian sectors}

As noted, the estimation of agrarian capital's profits is needed to measure the portion of ground-rent appropriated by landowners. For that purpose, it is first necessary to measure the amount of agrarian capital advanced for valorisation $(K)$ and the rate of profit of industrial capital, which in turn requires comparing the surplus-value appropriated in the industrial sector with the amount of capital advanced for that purpose. Regardless of the sector of investment, the latter is composed of two parts: fixed (FK) and circulating ('working') portions (CK). From the point of view of macroeconomic accounting, FK includes all means of production with a turnover period greater than one year - i.e., those whose use-value is consumed, and thus its value transferred to the product, throughout periods longer than one year. This includes buildings, machinery, equipment, and transport material. The circulating portion of capital includes all means of production with a turnover period shorter than one year (i.e., raw and auxiliary materials) and labour-power. Turnover period refers here to the time that takes a specific portion of capital to fully return to the money-form in which 
was originally advanced. ${ }^{14}$ The following formula synthetises the composition of capital according to the turn-over period of its different material elements:

$$
K_{i}=F K_{i}+C K_{i}
$$

The magnitude of fixed capital yearly advanced for valorisation is equal to the addition of the net value of the different instruments of production $(f k)$, as defined in the following formula.

$$
F K_{i}=\sum_{y}^{n} f k_{y i}
$$

The magnitude of circulating capital advanced for valorisation every year is equal to the addition of the mass of capital in the form of direct wages and other indirect forms of compensation of the labour-force (W), raw and auxiliary materials (M) divided by the number of times (v) their value turns, on average, over during one year.

$$
K C_{i}=\left(W_{i}+M_{i}\right) \div v_{i}
$$

Figure 4 plots the evolution of the amount of capital advanced for valorisation in the agrarian and industrial sectors of the Brazilian economy.

Figure 4: Capital advanced for valorisation - in million $2004 \mathrm{R} \$$

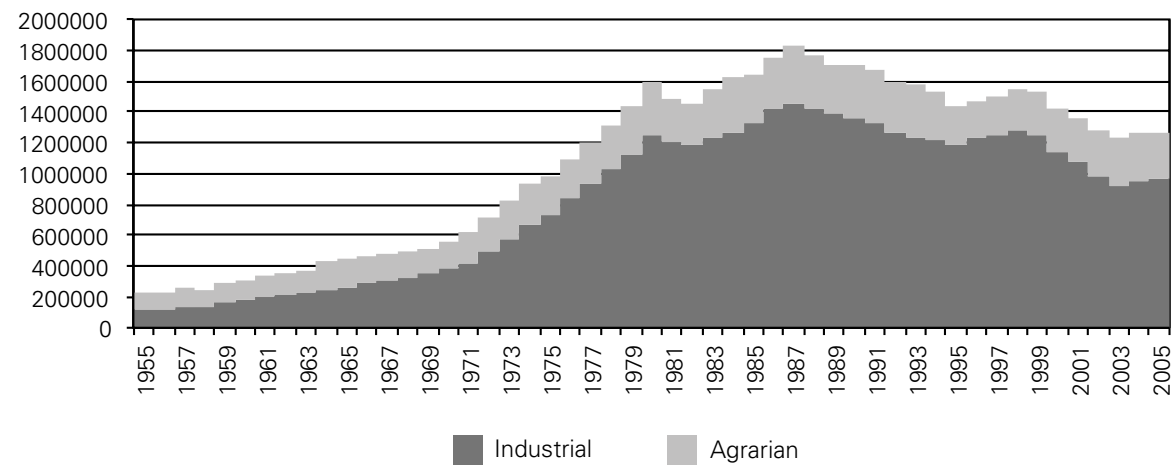

Source: Grinberg (2011).

From Figure 4, it can be seen that the amount of capital advanced for valorisation in the industrial sector grew strongly until around 1980, crucially during the 'big push' into heavy industry of the 1970s, and entered a downward trend between then and the mid-2000s. A relatively similar evolution is observed in the agrarian sector, though the stock of capital did not fall after the mid-1980s but stop growing.

\footnotetext{
${ }^{14}$ See Marx (1992, pp. 236-61) for the analysis of the process of turn-over of industrial (productive) capital.
} 


\section{Rate of profit of industrial capital}

The rate of profit, that is the rate of valorisation of capital, is obtained by dividing the total surplus-value appropriated in the economy, or a specific branch, in a given period of time by the total amount of capital (i.e., fixed plus circulating) advanced to obtain them. Thus the formulas to measure sectoral rates of profit are the following.

$$
\pi_{y i}=\prod_{y i}=\div K_{y i}
$$

Where,

$\pi_{y i}$ is the average rate of profit in the sector $y$ the year $i$.

Figure 5 compares the evolution during 1957-2005 of the rate of profit of industrial capital in Brazil and in the USA.

Figure 5: Pre-tax rate of profit of industrial capital

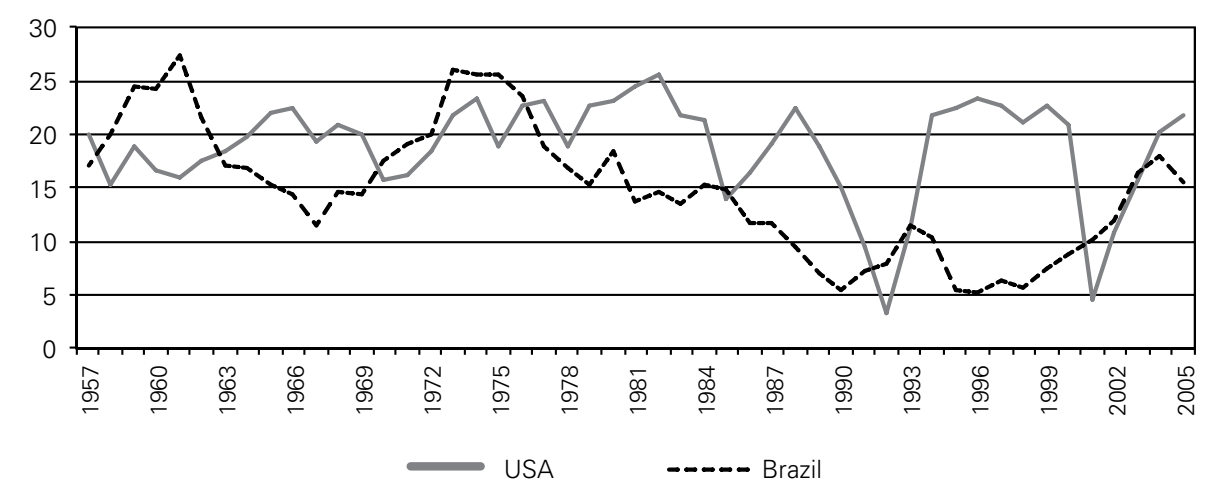

Source: Grinberg (2011).

Several observations can be made from Figure 5. First, it can be seen there that the average rate of profit of industrial capital in Brazil remained relatively high, at levels comparable to those obtained in the USA, during the entire pre-1980 period, when the process of capital accumulation through ground-rent recovery came about through 'state-led' ISI. In Grinberg (2013a, 2013b), it was argued that during this period the mass of ground-rent appropriated by industrial capital grew, on average, faster than the former's requirements to compensate for the low level of productivity of the labour it set in motion and, hence, for its relatively high (for world-market norms) production costs. Yet, some differences are observed within this period. The rate of profit of industrial in Brazil peaked during the implementation of the 1956-60 'developmentalist' Targets Plan, the 'miraculous' years of 1968-1973 and the early phase of the Second National Development Plan (1974-1976); and, fell, albeit from high levels, during the slow-growth period of the early 1960s, and during the latter part of the 1970s. Secondly, it can be seen that the rate of profit of industrial capital in Brazil collapsed thereafter, while the process of capital ac- 
cumulation began come about through increasingly 'neoliberal' policies. It only recovered after the late 1990 s as industrial-sector wages had fallen below $40 \%$ of those prevailing in the mid-1980s (Grinberg, 2013a).

\section{Ground-rent appropriated by landowners}

Armed with the measurements presented in the previous sections, it is now possible to plot the estimation of the magnitude of the portion of Brazilian ground-rent effectively appropriated by landowners. In Figure 6 below, this is compared with the portion appropriated by other social subjects estimated in Grinberg (2008, $2013 \mathrm{~b}$ ). The latter, it should be noted, also includes the portion of the mining ground-rent appropriated by others than landowners.

Figure 6: Ground-rent appropriation

in million $2004 \mathrm{R} \$$

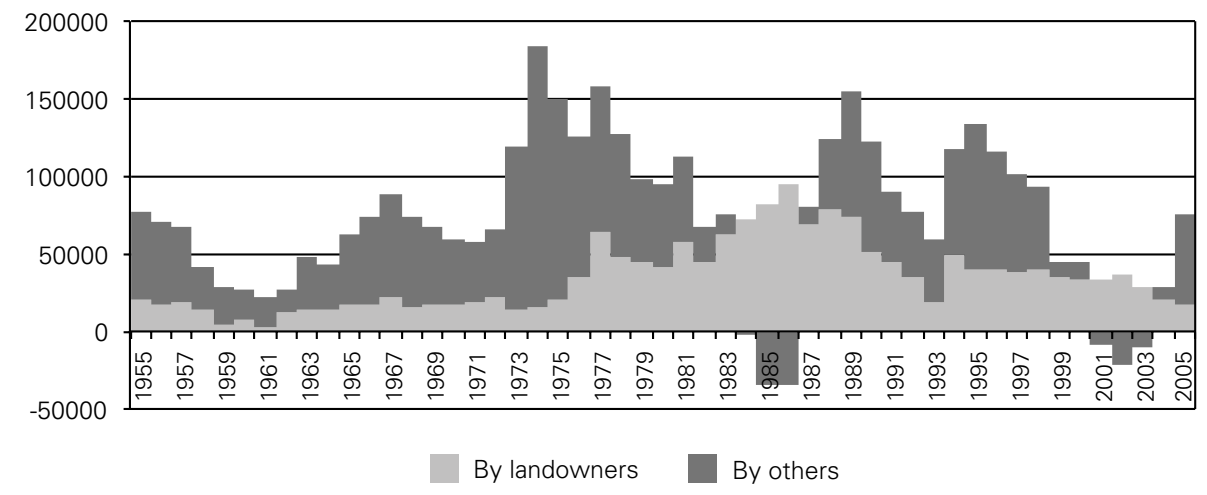

Source: Grinberg (2013a:195)).

Several observations can be made from Figure 6. First, it can be seen that the ground-rent appropriated by landowners remained practically stagnant between the mid-1950s and the early 1970s, though it contracted briefly during second part of the 1950s as global primary-commodity prices fell strongly in the aftermath of the Korean War. Secondly, that the portion of the rent appropriated by landowners expanded during the 1970s, as primary-commodity prices and agrarian output increased strongly, and during the middle part of the 1980s, despite the opposite occurred. During 1984-87, the strong undervaluation of the national currency, product of the state's external-debt repayment policy, channelled normal surplus-value from capital to landowners (Grinberg, 2013b). Finally, Figure 6 also shows that the mass of ground-rent appropriated by landowners fell back to normal levels thereafter. 


\section{TOTAL GROUND-RENT}

The magnitude of the total ground-rent (TR) available for appropriation in Brazil is then measured by adding up the portions appropriated by landowners and by other social subjects as in the following equation.

$$
T R_{i}=A O R_{i}+L R_{i}
$$

Where,

$A O R i$ is the ground-rent appropriated by others than landowners during year $i$;

$L R i$ is the ground-rent appropriated by landowners during year $i$.

Figure 7 plots the evolution of total ground-rent appropriated by different social subjects in the Brazilian economy between 1955 and 2005.

Figure 7: Total Ground-rent

in million $2004 \mathrm{R} \$$

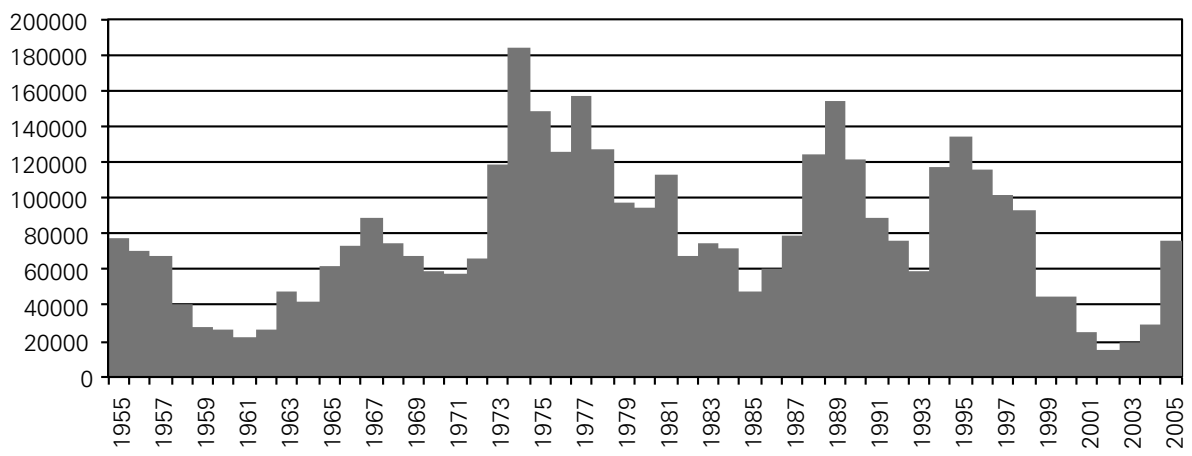

Source: Grinberg (2011)

In Figure 7, it can be observed there that the total ground-rent appropriated in the Brazilian economy contracted during the second half of the 1950s, after picking up during the 'commodities boom' associated with the Korean War; it recovered during the first half of the 1960s but stagnated during the latter part of that decade; it expanded strongly during the 1970s as the agrarian frontier expanded and international primary-commodity prices spiked; it collapsed during the 1980s and early 1990s as international commodity prices fell strongly; it recovered during 1988-90 and 1994-98 as prices increased and agrarian output expanded mildly; collapsed during 1999-2003 as primary-commodity prices fell again sharply as a result of weak global demand; and, expanded strongly after 2004 as international prices of raw materials recovered and, crucially, primary-sector production increased. 


\section{RELATIVE IMPORTANCE OF GROUND-RENT IN THE BRAZILIAN ECONOMY}

Finally, this section assesses the relative importance of ground-rent in the Brazilian economy. Figure 8 below plots the evolution of the total ground-rent (GR) and of the portion of the rent effectively appropriated by landowners (LR) relative to total surplus-value (SV) or net surpluses. Figure 8 also shows the evolution of the ground-rent appropriated by landowners against Gross domestic product (GDP).

Figure 8: Relative importance of ground-rent in the Brazilian economy

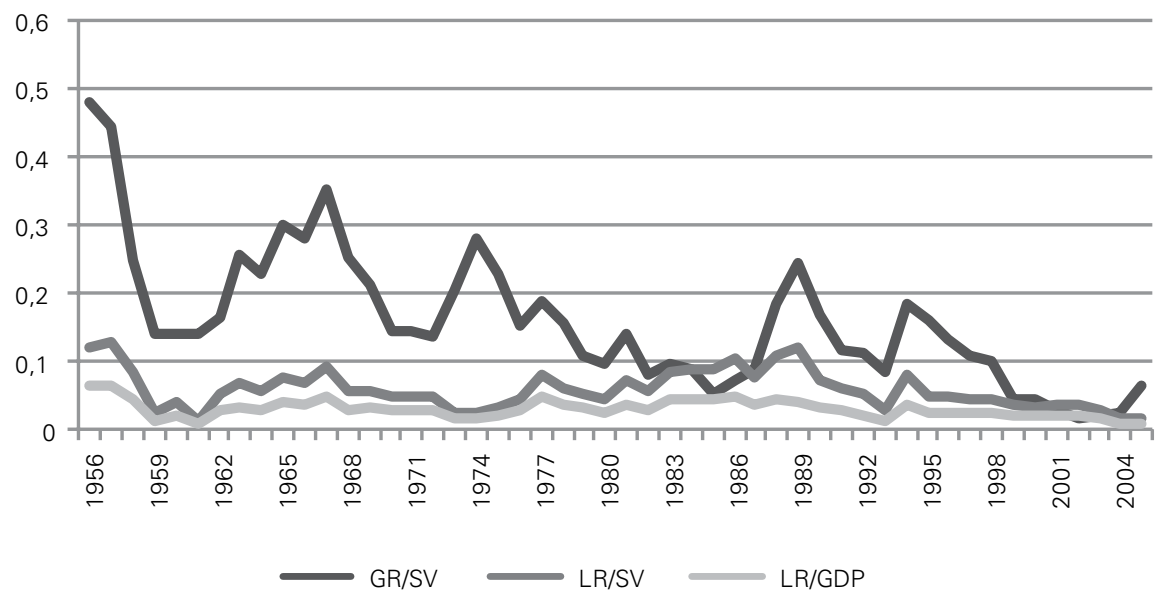

Source: Grinberg (2011).

Figure 8 reveals that the ground-rent appropriated by different social subjects remained a substantial portion of total surplus-value throughout the entire 1955-2005 period, averaging $16 \%$. Yet, there have been marked differences across sub-periods. The ground-rent equalled $26.5 \%$ of total surplus-value during 1955 -1963, when the 'classic' or 'state-led' ISI process accelerated under 'developmentalist' governments; $16 \%$ of total surpluses during 1964-1980, when the ISI process 'deepened' under military rule; only $2.5 \%$ during the 'lost decade' of the 1980 s, when the 'state-led' ISI process entered into a deep crisis; and 9\%, thereafter, when the process of capital accumulation through ground-rent recovery began to reproduce itself under neoliberal forms (i.e. a limited ISI process). Nevertheless, despite the post-1980 relative decline, the ground-rent was equal to approximately $15 \%$ of total surpluses during the relatively high growth period of 1994-1997. The portion of the agrarian ground-rent effectively appropriated by landowners during 1955-2005 averaged 3\% and 6\% of GDP and total surpluses, respectively. 


\section{CONCLUSIONS}

This paper put forward an original measurement of the Brazilian ground-rent effectively appropriated by landowners. In pursuing this task, the paper also presented original estimations of various time-series that are crucial for any analysis of the long-term performance of the Brazilian economy. This included the stock of capital in the agrarian and industrial sectors, the masses of surplus-value appropriated by industrial and agrarian capital and the average rate of profit of industrial capital. These time-series cover the period 1955-2005.

The measurements presented here complement those advanced in Grinberg (2008, 2013b), making it possible to have an estimation of the total size of the mass of surpluses (surplus-value) determined in the unity of the world market as Brazilian ground-rent. This measurement is crucial for the understanding of a process of capital accumulation, as the Brazilian, that has revolved around the appropriation of the local ground-rent by different social subjects. It was seen in this paper that while the ground-rent appropriated by landowners remained a fairly stable portion of total surpluses and national income throughout much of the post-WWII period, that appropriated by others, and hence the total ground-rent, experienced notable changes.

\section{REFERENCES}

Abreu, M. de Paiva (2008), 'The Brazilian economy, 1930-1980', in L. Bethell (ed.), The Cambridge History of Latin America Volume IX, Brazil since 1930, Cambridge: Cambridge University Press.

Alves, P. and A. Messa Silva (2008), 'Estimativa do estoque de capital das empresas industriais brasileiras', Texto para Discussão No. 1325, Instituto de Pesquisa Econômica Aplicada.

ANFAVEA (2008), Brazilian Automotive Industrial Yearbook, ANFAVEA, São Paulo.

Bacha, E., et al. (1972), 'Encargos trabalhistas e absorção de mão de obra: Uma interpretação do problema e seu debate', Relatorios de Pesquisa, Instituto de Planejamento Econômico e Social, 12, IPEA/INPES, Rio de Janeiro.

Brenner, R. (2006), The Economics of Global Turbulence, London: Verso Books.

Bresser-Pereira, L.C. (2008), 'The Dutch disease and its neutralization: a Ricardian approach', Brazilian Journal of Political Economy, 28 (1), pp. 47-71.

Bresser-Pereira, L.C. (2013), 'The value of the exchange rate and the Dutch disease', Brazilian Journal of Political Economy, 33 (3), pp. 371-387.

CEPAL/BNDE (1956), Análisis y Proyecciones del Desarrollo Económico: El desarrollo económico del Brasil, Naciones Unidas, Departamento de Asuntos Económicos y Sociales, México.

Chacel J.M. (1967), 'O setor agricola, a renda nacional e a taxa de investimento', Revista Brasileira de Economia, 4, pp. 50-60.

Correa de Lago, L.A. (1990), ‘A retomada do crescimento e as distorções do “milagre”: 1967-1973', in Abreu, M. de Paiva et al., A Ordem do Progresso: Cem anos de Politica Economica Republicana (1889-1989), Rio de Janeiro: Campus. 
Franco, G. (2000), 'The Real plan and the exchange rate', Essays in International Finance, No. 217, Princeton University, New Jersey.

Ghilardi, A. (2005), 'Custo operacional básico e receita líquida de laranja para indústria na região norte do estado de São Paulo, safra agrícola 2003/4', Informações Econômicas, 35 (3).

Fonseca, R. and T.C. Mendes (2002), 'Produtividade do capital na indústria brasileira', Texto para Discussão No. 2, Confederação Nacional da Indústria, Brasília.

Fundação Getulio Vargas, Conjuntura Econômica, IBRE, various issues.

Grinberg, N. (2008), 'From the 'miracle' to the 'lost decade': Intersectoral transfers and external credit in the Brazilian economy', Brazilian Journal of Political Economy, 28 (2). p. 291-311.

Grinberg, N. (2011), 'Transformations in the Brazilian and Korean processes of capitalist development: the political economy of late-industrialisation', PhD thesis, London School of Economics and Political Science.

Grinberg, N. (2013a), 'The political economy of Brazilian (Latin American) and Korean (East Asian) long-term development: moving beyond nation-centred approaches', New Political Economy, 18 (2), pp. 171-197.

Grinberg, N. (2013b), 'Capital accumulation and ground-rent in Brazil: 1953-2008', International Review of Applied Economics, 27 (4), pp. 449-471.

Grinberg, N. and G. Starosta (2014), 'From global capital accumulation to varieties of centre-leftism in South America: The Cases of Brazil and Argentina', in J. Webber and S. Spronk (eds.), Crisis and Contradiction: Marxist Perspectives on Latin America in the Global Economy, Leiden: Brill Academic Publishers, Historical Materialism Book Series.

IBGE, Agrarian Census, various issues.

IBGE, Demographic Census, various issues.

IBGE, National Household Sample Survey, various issues.

IBGE, Statistics on Foreign Trade, various issues.

Instituto do Café (1976), Boletim Estatístico, various issues.

Iñigo Carrera, J. (2007), La formación Económica de la Sociedad Argentina, Buenos Aires: Imago Mundi.

Iñigo Carrera, J. (2008), El Capital: razón histórica, sujeto revolucionario y conciencia, Buenos Aires: Ediciones Cooperativas.

Langoni, C. (1974), As Causas do Crescimento Economico do Brasil, Rio de Janeiro: APEC Editora.

Marx, K. (1992), Capital Volume II, London: Penguin Books.

Marx, K. (1981), Capital Vol. III, Harmondsworth: Penguin Books.

Morandi, L. and E. Reis (2004), 'Estoque de capital fixo no Brasil - 1950-2002', XXXII Encontro Nacional de Economia, ANPEC.

Paiva Badiz Furlaneto, F. et al. (2005), 'Custo de produção e rentabilidade da cultura da banana 'Maçã' na região do médio Paranapenema', Informações Econômicas, 35 (12), pp. 19-25.

Radetzki, M. (2006), 'The anatomy of three commodity booms'. Resources Policy, 31, pp. 56-64.

Ricardo, D. (2001), On The Priniples of Political Economy and Taxation, Ontario: Batoche Books.

Rodrigues Vegro, C. (2004), 'Lucro na cafeicultura: miragem ou concreta possibilidade?', Instituto de Economia Agrícola, São Paulo, mimeo.

Salama, P. (1978), 'Specificite de l'internationalisation du capital en Amerique Latina.' Revue Tiers Monde, 19 (74), pp. 259-297. 
Santana Ferreira (1992), 'Cacao standard production cost monitoring in Bahia, Brazil', Agrotopica, 4 (3), Centro de Pesquisas do Cacau, Ilhéus, Bahia.

Serra, J. (1982), 'Ciclos e mudanças estruturais na economia brasileira de pós-guerra', in Gonzaga M. Belluzzo, L. and R. Coutinho (eds.), Desenvolvimento Capitalista no Brasil, São Paulo: Editora Brasiliense.

US Bureau of Census (1975), Historical Statistics of the United States, Colonial Times to 1970.

US Bureau of Census, 'Quarterly financial report for manufacturing, mining and trade corporations', various issues.

\section{APPENDIX: METHODOLOGICAL BASES AND SOURCES ${ }^{15}$}

\section{CONSUMER PRICE INDEX}

\section{Methodology and sources}

The Consumer Price Index (CPI) produced by the Getulio Vargas Foundation (FGV) is used here instead of the Augmented Consumer Price Index (IPCA) published by the Brazilian Institute of Geography and Statistics (IBGE). Two reasons assist this choice. First, the CPI-FGV is the first of such indices produced in Brazil and, for that reason, the only one that covers the entire period under study keeping methodological consistency. Its origins date back to the early 1940s, when it was calculated for the city of Rio de Janeiro. A correction, using the re-estimation available in Correa do Lago (1989, p. 248) and Abreu (2008a, p. 373), was made on the original time-series for 1973 . That year, the inflation rate measured by the FGV was grossly underestimated, under pressure from the military attempting to keep readings low for political and policy purposes. The original reading of $13.7 \%$ was changed for the subsequent re-estimation of $26.6 \%$. Secondly, the IPCA, produced by the IBGE since 1980, suffered several, often spurious, manipulations and methodological changes with the purpose of reducing the official inflation readings, crucially in 1990-92, when the Collor Plan was implemented, and during July-August 1994, when the Plan Real was launched and the so-called 'residual' inflation was removed from the index. ${ }^{16}$

\section{GROSS FIXED CAPITAL FORMATION DEFLATOR}

\section{Methodology and sources}

They are computed dividing the time-series of gross fixed capital formation in

\footnotetext{
${ }^{15}$ All base and derived time-series used in this paper are available in Grinberg (2011, pp. 443-521).

${ }^{16}$ See the theoretically weak defence of this manipulation put forward by Gustavo Franco (2000, p. 8), then president of the Brazilian Central Bank and mastermind of the Plan Real.
} 
current prices for those in constant prices. They are computed for total Gross fixed capital formation, 'Constructions' and 'Machinery and equipment'.

a) 1950-2005: The time-series of Gross fixed capital formation are estimated by the IBGE and are available in Ipeadata.

\section{AGRARIAN AND INDUSTRIAL GDP AT FACTOR COSTS}

\section{Sources}

a) 1955-2005: The time-series of sectoral GDP are estimated by the IBGE (available in Ipeadata).

\section{TOTAL LABOUR COSTS IN THE INDUSTRIAL SECTOR}

\section{Methodology and sources}

The time-series of the total cost of industrial labour-power was constructed by adding-up the annual cost of the labour-force in formal employment contracts and the annual cost of those employed without formal employment contracts. The former was obtained by multiplying the average wage in the sector plus employer contributions to social security by the total amount of the formally employed labour-force. The latter was calculated multiplying the average wage by the quantity of informal workers, obtained by ducting the amount of formally employed industrial labour from the total industrial labour-force. Industrial wages were computed by dividing the wage mass with the number of workers employed during the relevant year. Indirect wages were calculated by multiplying direct wages with the rate of employer contribution to social security.

\section{Wages}

a) 1955-1975: Base time-series were obtained from the Annual Industrial Survey (PIA) undertaken by the IBGE.

b) 1976-2008: Values were estimated using an index of nominal wages for industrial workers in the metropolitan area of São Paulo, Brazil's largest industrial district, produced by the Federation of São Paulo Industrial Companies (FIESP).

\section{Rate of employer contributions to social security}

a) 1954-1969: It was obtained from Bacha et al. (1972, p. 165).

b) 1975: It was obtained from Conjuntura Econômica, June, 1975.

c) 1980: It was obtained from Conjuntura Econômica, April, 1980.

d) 1976-1979: It was estimated taking the weighted average of 1975 and 1980 values.

e) 1988-1990, 1992-1993 and 1997-2007: It was computed by dividing the value of total contributions by the value of total wages published in the PIA.

f) 1991: It was estimated taking the average of 1990 and 1992 values. 
g) 1994-1995: It was estimated taking the average of 1993 and 1996 values.

\section{Total industrial labour force}

a) 1955-2005: The time-series was taken obtained from the ' 10 -sector' database produced by the Groningen Growth and Development Centre (GGDC). This information is compatible with that compiled in the Demographic Censuses and the National Household Sample Survey (PNAD).

\section{Industrial workers with formal employment contracts}

a) 1989-2005: It was taken from the Ministry of Labour RAIS database.

b) 1981-1988: Generated using rates of growth of an index of industrial employment on São Paulo produced by FIESP (available in Ipeadata).

c) 1955-1987: Generated using rates of growth of the values presented in the PIA.

\section{TOTAL LABOUR COSTS IN THE AGRARIAN SECTOR}

\section{Methodology and sources}

The total cost of the rural labour-force (employees, self-employed and family workers) was computed using available estimations of 'labour's share' in agrarian valued-added, and multiplying these values by the valued-added in the sector. Multiplying rural wages by rural workforce overestimates total labour costs; this method does not account for large underemployment in the sector.

\section{Total labour costs}

a) 1962-1963: It was taken from Chacel (1967) based on a FGV study.

b) 1970, 1975, 1980, 1985, and 1995/6: It was obtained from Prado Lima (2007) who estimated the values using Rural Census data.

c) The rest of the time-series was estimated taking weighted averages of values available.

\section{STOCK OF FIXED CAPITAL IN THE INDUSTRIAL SECTOR}

\section{Methodology and sources}

Due to the lack of information on gross capital formation, the time-series of total fixed capital annually advanced for valorisation in the industrial sector was calculated by applying the rate of growth of different estimations available to an initial (1954) value. The value for 1954 was estimated using the capital to output ratio calculated in CEPAL/BNDE (1956) for those industrial sectors directly or 
indirectly producing consumer goods. ${ }^{17}$ An annual average depreciation rate of $3.7 \%$ of the net value of the capital stock estimated in Morandi and Reis (2002) for economy-wide fixed capital stock was used to calculate the consumption of fixed capital.

a) 1955-2003: The time-series was generated using the rate of growth of the following estimations of the stock of fixed capital in the industrial sector:

a.1) Serra (1982) for the period 1955-1980.

a.2) Fonseca and Mendes (2002) for the period 1981-1995.

a.3) Alves and Mesa Silva (2008) for the period 1996-2003.

b) 2004-2005: It was estimated using the rate of growth of total (economywide) fixed capital stock available in Ipeadata.

\section{STOCK OF FIXED CAPITAL IN THE AGRARIAN SECTOR}

\section{Methodology and sources}

There is no official publication of the time-series of gross capital formation in the agrarian sector. Data specific to the agrarian sector is included in the aggregated 'private sector' gross capital formation account. Nor is there a unofficial estimation of the stock of agrarian capital. For this reason, the estimation of the annual stock of fixed capital in the sector (i.e., machinery, buildings, plantations and livestock) had to be done following a different methodology than that used for the industrial sector.

The stocks of fixed capital in the form of machinery were estimated through the perpetual inventory method. ${ }^{18}$ The apparent consumption of the different types of machinery (tractors, cultivators and harvesters) was used as a measure of investment flows. In the case of milking machines, due to the lack of information, only imports were computed as investments in this type of fixed capital. Data from ANFAVEA (2008) was used for domestic production of tractors, cultivators and harvesters. Data from FAOSTAT was used for the number of tractors imported between 1950 and 2005. Information from UN Comtrade database was used for imports in domestic currency of other types of agricultural machinery. Prices of agricultural machinery published by the São Paulo Institute of Agrarian Economics (IEA) for 2005 and an index of prices of rural tractors (see below) were used to

\footnotetext{
${ }^{17}$ This study, conducted by the United Nations Economic Commission for Latin America and the Caribbean, known as ECLAC (originally ECLA) and the recently established Brazilian National Development Bank (Banco Nacional do Desenvolvimento, BNDE), was part of region-wide project coordinated by the UN ECLA. This project developed for the first time a uniform methodology to undertake a wide and exhaustive study of the state of Latin American economies and their growth potentialities. In some sense, this project informed the subsequent wave of developmentalist policies across the region.

${ }^{18}$ This method consists of generating the first value of the time-series by adding the flow of investments on a specific instrument of production and deducting its annual consumption for a period of time equivalent to its useful life.
} 
generate the time-series of prices for 1955-2005. For imports before 1960, data published in the Statistics on Foreign Trade by the IBGE was used. A 5\% depreciation rate (i.e., 20 years of useful life) was used to calculate the annual consumption of this type of fixed capital.

The estimation of the stocks of fixed capital in the form of rural buildings was done adding the flow of investments and deducting the consumption (depreciation) of fixed capital to an original stock. Langoni's estimation of the total stocks of rural constructions for 1953 was used for the first value of the timeseries. The estimation of annual investments in rural constructions for 1950-1969 was done by the IBGE (unpublished material) and reproduced in Langoni (1974). For 1970-2005, information on investments in rural commercial buildings is only available for the census years of 1970, 1975, 1980, 1985, and 1995-6. The rest of the time-series was estimated using the weighted averages of the sector's investments-to-value-added ratios. Only $63 \%$ of the original stock and investments in rural buildings were considered as part of the stock of fixed capital advanced for valorisations in the form of commercial buildings in the agrarian sector. The other $37 \%$ was considered to be residential buildings. The relationship between residential and non-residential constructions was taken from the Agrarian Censuses. The $63 \%$ mentioned above is an average of the values of the different census years.

The annual value of the stock of fixed capital in the form of perennial plantations was estimated using the following methodology. The number of trees of coffee, cocoa, oranges and banana, the four main perennial plantations in Brazil, in existence every year between 1940 and 2005 was estimated using the information of the number of trees per harvested area presented in the different Agrarian Census and the information of annual harvested area published by the IBGE. For the case of coffee, direct information produced by the Brazilian Coffee Institute (1976) was used for the period 1950-1970. In order to calculate the value of the trees in existence, the cost of implantation and the average remaining useful life of each tree had to be estimated. The former was done using information on costs of implantation for coffee in 2003, cocoa in 1987, oranges in 2003 and banana in 2005 presented in Rodrigues Vegro (2004), Santana Ferreira (1992), Ghilardi (2005) and Paiva Badiz Furlaneto (2005) respectively. The rest of the time-series was estimated using the prices implicit in fixed gross capital formation. The useful life of each tree was estimated using an iterative model that considers that if tree populations remain constant (i.e., new plantations only replace worn out ones), the average life of each tree is equal to the average of its useful life. Increases or decreases in the stock of trees are then factored in the equation, modifying the average age of each tree, downwards when new plantations exceed retirements and vice versa. The average remaining life of each tree is calculated by deducting the average age from the average useful life. The following useful life periods of full productive capacity were used: 15 years for coffee, banana and orange trees, and 40 years for cacao. These averages are used in the sources mentioned above. 
The annual value of the stock of animals was computed by multiplying the number of animals by their prices. As livestock reproduces itself indefinitely, a turnover speed equal to infinity was used to represent the annual consumption of this type of fixed capital. In other words, livestock is always considered to be worth its full face value.

\section{Stock of animals}

a) 1955-2005: The number of animals for livestock production was gathered from FAOSTAT.

\section{Prices of livestock}

a) 1955-1990: Prices for the different types of animals were obtained from various issues of the Statistical Yearbook produced by the IBGE.

b) 1991-2005: They were estimated using price indices constructed for each type of animal. This information was obtained from the database of the São Paulo IEA. When no specific information was available (i.e., birds and sheep) a composite index of animals prices was used instead.

\section{CIRCULATING CAPITAL IN THE AGRARIAN SECTOR (EXCLUDING LIVESTOCK)}

\section{Methodology and sources}

The value of circulating capital advanced for valorisation was calculated by dividing the annual value of wages and of non-wage expenditures (i.e., intermediate consumption) by the number of times that this type of capital turns over per year.

\section{Turnover speed}

The average turnover of 2 times per year estimated in Iñigo Carrera (2007) for agrarian productions in Argentina is used here as a proxy for the rate of turnover of circulating capital in the Brazilian agrarian sector. This average calculated through various studies cited in that source, includes almost all the most important agrarian productions undertaken in Brazil under relatively similar productive and commercial conditions. Moreover, this value seems a good approximation considering that most agrarian production processes take place once a year with the corresponding labour-processes extending through several months. The circulating capital required for these processes (e.g., seeds, fertilizers, and labour-power) tends to be disbursed across the year with disbursements on inputs concentrating during the sowing period and on labour-power during harvesting time. ${ }^{19}$ In any case, giv-

\footnotetext{
${ }^{19}$ If circulating capital is disbursed evenly across an annual production process, the average turn-over
} 
en that circulating capital has constituted a relatively small fraction of total agrarian capital (22.5\% average during 1955-2005 under the unrealistic assumption that its components turn over only once per year), measurement errors associated with the treatment given here are negligible.

\section{Non-wage production costs}

a) 1955-2005: Values were estimated using the relationship between intermediate consumption and value-added in the sector published in the input-output tables of 1959, 1970, 1985, 1995 and 1996. The rest of the information was generated using weighted averages of that relationship and the time-series of agrarian value-added.

\section{CIRCULATING CAPITAL IN THE INDUSTRIAL SECTOR}

\section{Methodology and sources}

The same methodology used for agrarian circulating capital.

\section{Turnover speed}

The turnover speed of inventory stocks was used as a proxy for the turnover speed of circulating capital in the industrial sector. The data of the former for a sample of 665 medium and large size industrial companies during 1981-1987 was published in Conjuntura Econômica (1988). The average of those years, 6.18 times a year, was used for the entire period 1955-2005.

\section{Non-wage production costs}

a) 1955-2005: Values were estimated using the relationship between intermediate consumption and value-added published in the input-output tables of 1959, 1970, 1985,1995 and 1996. The rest of the information was generated using weighted averages of that relationship and the time-series of the sector's value-added.

\section{RATE OF PROFIT OF US INDUSTRIAL CAPITAL}

\section{Methodology and sources}

In the absence of a time-series of the rate of profit of industrial capital for the period analysed here, either by mainstream or critical economists, the rate of return

period of this portion of capital approximates to 2 . 
of 'manufacturing corporations' calculated by the US Bureau of Census was used as an approximation.

a) 1957-1970: This time-series is taken from US Bureau of Census (1975).

b) 1971-2005: Taken form several issues of the 'Quarterly Financial Report for Manufacturing, Mining and Trade Corporations' by the US Bureau of Census. 